\title{
CONTAMINATION OF THE ENVIRONMENT BY PATHOGENIC BACTERIA IN A LIVESTOCK FARM IN LIMPOPO PROVINCE, SOUTH AFRICA
}

\author{
Chitura, T. ${ }^{1 *}-$ ShaI, K. ${ }^{1}-$ NCUBe, I. $^{2}-$ VAN HeERdEN, H. $^{3}$ \\ ${ }^{I}$ Department of Agricultural Economics and Animal Production, University of Limpopo \\ Private Bag X1106, Sovenga 0727, South Africa \\ ${ }^{2}$ Department of Biochemistry, Microbiology and Biotechnology, University of Limpopo \\ Private Bag X1106, Sovenga 0727, South Africa \\ ${ }^{3}$ Department of Veterinary Tropical Diseases, University of Pretoria \\ Private Bag X04, Onderstepoort 0110, South Africa \\ *Corresponding author \\ e-mail:teedzai.chitura@ul.ac.za \\ (Received $2^{\text {nd }}$ Nov 2018; accepted $11^{\text {th }}$ Jan 2019)
}

\begin{abstract}
The aim of this study was to investigate the occurrence and diversity of pathogenic bacteria in the environment at a livestock farm in Limpopo Province. Environmental samples were collected from three sampling locations: cattle camp (CC), sheep camp (SHC), and goat camp (GC). Samples were processed and analysed for total bacterial counts in the Biotechnology Laboratory, University of Limpopo, South Africa. Identifications were done with Matrix Assisted Laser Disorption Ionisation Time of Flight Mass Spectometry (MALDI-TOF MS) using the simplified on plate technique. The colony forming unit formula per gram of environmental sample $(\mathrm{CFU} / \mathrm{g})$ was used to determine total bacterial counts. High counts were observed in CC and low counts in SHC for both soil and faecal samples. Bacillus species were the most dominant across the sampling locations for soil samples. Bacillus cereus occurred in 36 samples (33\%), however, the frequency of isolation dominated in the CC with (44.4\%), GC $(22.2 \%)$ and SHC (13\%). Staphylococcus aureus had the least frequency $(2.2 \%)$ followed by Listeria monocytogenes $(4.4 \%)$. In faecal samples, the occurrence and level of contamination with bacterial species varied across sampling locations with Escherichia coli dominating in the CC with $20 \%$ frequency, and abscent from SHC and GC.
\end{abstract}

Keywords: MALDI-TOF MS, livestock diseases, soil, Escherichia coli, Bacillus cereus

\section{Introduction}

The rural communities of South Africa depend on livestock farming in various ways such as the provision of meat, milk, manure, improved livelihoods and socioeconomic relief (Meissner et al., 2013; Becker, 2015; Madziga et al., 2013). However, livestock diseases present a major threat to animal health. The increase in the circulation of infectious agents over the past decade as well as the emergence of antibiotic resistance and environmental pollution has placed human and animal health at risk. This highlights the importance of human-animal ecosystem interfaces in the evolution of emergence of pathogens (Destoumieux-Garzon et al., 2018). A better knowledge of causes and consequences of certain human activities, lifestyles, and behaviour in ecosystems is crucial for a rigorous interpretation of disease dynamics.

Threats from old and new pathogens continue to emerge as a result of changes in the climatic conditions. Young growing animals on pasture are especially prone to spore forming bacteria of the Bacillus and Clostridium spp. Livestock acquire the spores 
during grazing on contaminated pastures (Lange et al., 2010; Cooper and Valentine, 2016). Once the bacteria are in abundance on pasture, cases of the disease usually occur frequently in susceptible herds. Affected farms are usually those with irregular vaccination programs as farmers seek to minimise production costs (Maas, 2012). Limited studies focused on the ecology of transmission of livestock diseases (Morand and Figuié, 2016; Morand and Lajaurie, 2017; Cantor et al., 2017). In endemic areas, Bacillus and Clostridium spp may be present in soil and faeces (Dharmasena and Jiang, 2018). Christianssonn et al. (1999) reported bacterial contaminants of soil particularly Bacillus cereus to contaminate teats and udders of pasture fed cows leading to milk contamination and food borne diseases. Over the last few decades, several pathogens have either emerged or re-emerged. Livestock from small scale production systems in Limpopo Province suffer endemic diseases as they are kept under scavenging conditions which expose them to virulent factors.

In most cases, there is little attention to disease control and prevention in these livestock production systems (Gibbs, 2005). The extent of the diversity of microorganisms in soils determines the quality of pastures, since a wide range of pathogenic bacteria are involved in pasture contamination from livestock manure (Bagge et al., 2010). Bacterial species have always been of considerable medical and economic importance and the world is faced with changing landscape of infectious diseases due to pathogenic bacteria that affect man and animals posing significant threats to health and welfare of livestock (King et al., 2006). According to the 'one health', $60 \%$ of all human infections are directly or indirectly linked to livestock disease outbreaks (FAO et al., 2007). The documents and publications on the "One Health" approach, and the strategic framework developed around it, have largely focused on the battle against emerging zoonoses originating in domestic (Day, 2011) or wildlife (Dantas-Torres et al., 2012) and/or their interactions (Mencke, 2013). Bagge et al. (2010) reported manure to be the common pasture contaminant resulting in livestock infections. Based on the farm records, diseases and conditions such as blackleg, pulpy kidney, pink eye and mastitis are endemic at the farm. Therefore, identification of the causative agents in the farm is crucial for implementation of prompt therapeutic and control measures (Neumann et al., 2002). Therefore, the objectives of the study were to determine the total bacterial counts from environmental samples collected from the cattle and small stock camps in the farm using the colony forming unit (CFU) formula per gram of environmental sample and to identify the pathogenic bacteria isolated from soil and faecal samples.

\section{Literature review}

Arable land and pastures contaminated with the faeces of sick animals contribute considerably to pathogen transfer resulting in farm environment pollution (Trawińska et al., 2006; Nageswaran et al., 2012; Czekalski et al., 2012). Furthermore, the soil and manure in high producing farms provide diverse biological and physicochemical environments to microorganisms which pose a significant threat to humans and animals (Godwin and Moore, 1997; Whitman, 1998; and Douglas et al., 2003). Stecher and Hardt (2008) reported that bacteria in the gastro-intestinal tracts of animals can be excreted at high levels in faeces thereby contaminating soils and pastures. These bacteria may persist due to differences in local soil conditions (Dapilly and Neyrat, 1999; Gale, 2004). Extensive livestock farming poses a threat to the environment, as 
livestock shed millions of bacteria through their faeces and contaminate the soil and pastures thereby elevating the risk of disease breakouts. Nonetheless, disease outbreaks can be prevented through vaccination when local strains are recognised and safeguarding of human and animal health can be ensured (Radostitis et al., 2000; Amin et al., 2013; Manyi-Loh et al., 2016).

Livestock practices influence the microbial composition of faeces shed by animals (Wang et al., 2004; Manyi-Loh et al., 2016). The ability of these pathogens in manure to pollute, contaminate and infect the environment and livestock depends on the pathogen's ability to survive in manure following excretion or the hygiene practices to prevent its entry into the food chain (Wang, 2004). Studies on diversity of spore forming bacteria in cattle manure reported pathogenic bacteria of particular concern for animal health as, Clostridium spp, particularly (C. chauvoei, C. botulinum, C. tetani) and Bacillus spp (B. anthracis and B. cereus) (Bagge et al., 2010; Adak et al., 2002; Pachepsky et al., 2006; Pell, 1997; Plaut, 2000; Chauret et al., 1999). Campylobacter spp (C. jejuni and C. coli), Salmonella enterica (Adak et al., 2002; Pachepsky et al., 2006; Pell, 1997; Plaut, 2000), Yersinia spp (Y. enterocolitica and Y. pestis), Leptospira spp (L. interrogans) and Coxiella burnetii (Aitken et al., 2005; Nightingale et al., 2004), Mycobacterium avium sub species paratuberculosis, Listeria monocytogenes, Escherichia coli $O 157$ (Robert et al., 2017) are also reported as major threats to animal and human health. These bacterial species can cause serious clinical diseases in farm animals, when they are ingested in feed and have also been implicated in cases of food borne diseases in humans such as L. mocytogenes in human listeriosis.

Salihu et al. (2009) reported that Ca. jejuni and Ca. fetus cause abortion, stillbirths and birth of weak lambs in sheep during late pregnancy. The campylobacter species has highly been associated with feed contamination mostly in poultry as a result of faecal contamination. This alarms the need to identify these species at farm level so as to put hygiene strategies like proper manure management in place to prevent cross contaminations. Moreover, the depletion of medicinal plants due to increased population alarms the need to recognise local pathogen strains so that reliable drugs and vaccines can be produced for proper management of livestock diseases (Nishteswar, 2014). Thus, it is necessary that local pathogen strains be recognised so that vaccines can be developed for better disease management at farm level.

There is ample evidence showing that soil amendments that harbor enteric pathogens, such as raw animal manure or incompletely composted manure, are a means of introducing these pathogens in crop production systems (Kim et al., 2009; Nicholson et al., 2005; Ziemer et al., 2010). Products from mixed farming, including meat, eggs, and fresh produce, are at greater risk of cross-contamination as they are grown in the same facility and are currently considered to be high-risk foods (Adl et al., 2011). The source of contamination of fresh produce with enteric pathogens can frequently be traced back to environmental reservoirs associated with farm animals such as poultry, cattle, swine, goat, and sheep (Brinton et al., 2009; Park et al., 2014).

\section{Materials and methods}

\section{Description of the study area}

The study was carried out in a livestock farm in Limpopo Province, South Africa, coordinates: $23^{\circ} 49^{\prime} \mathrm{S} ; 2^{\circ} 41^{\prime}$ E. During the study period, no animal diseases or mortalities were reported. The total number of livestock kept at the farm was 225 
comprising 82 cattle, 77 sheep and 66 goats. The farm practices mixed livestock farming. Extensive livestock production system increases the chances of disease outbreak as livestock will have access to pastures and water supplies that may be contaminated with disease causing agents such as bacteria (McGuirk, 2015). The farm relies on chemoprophylaxis as a disease management tool, however, the practice is irregular. Environmental samples were collected from different resting points within camps in the farm. Figures 1-4 depict the environment from where samples were collected.

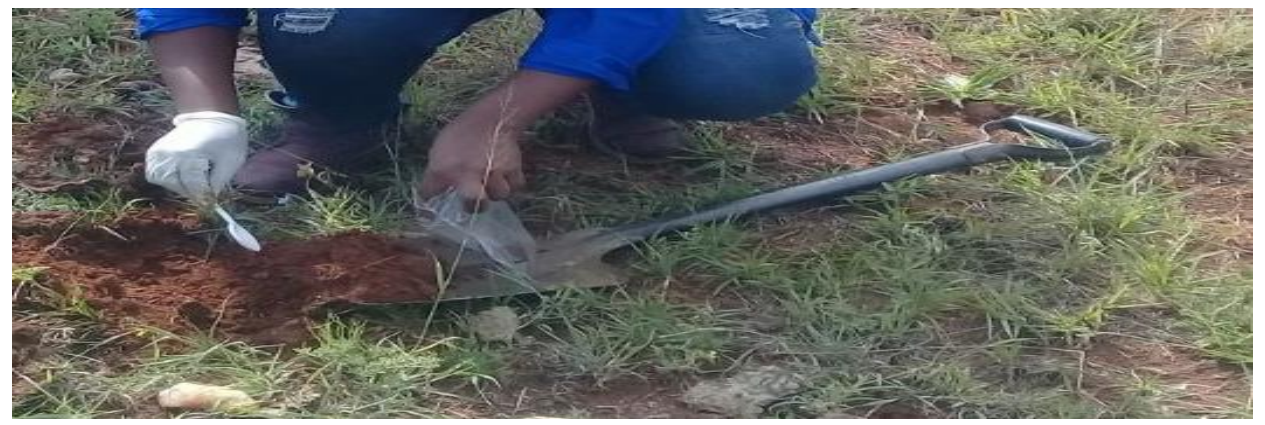

Figure 1. Collection of soil samples from resting points in the cattle camp in a livestock farm in Limpopo Province

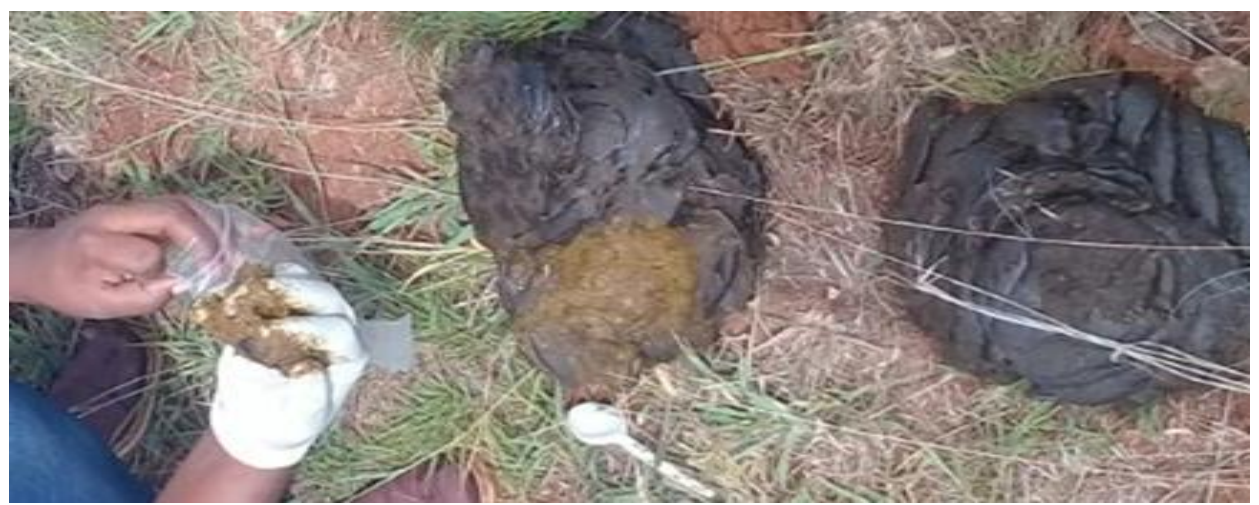

Figure 2. Collection of faecal samples from resting points in the cattle camp in a livestock farm in Limpopo Province

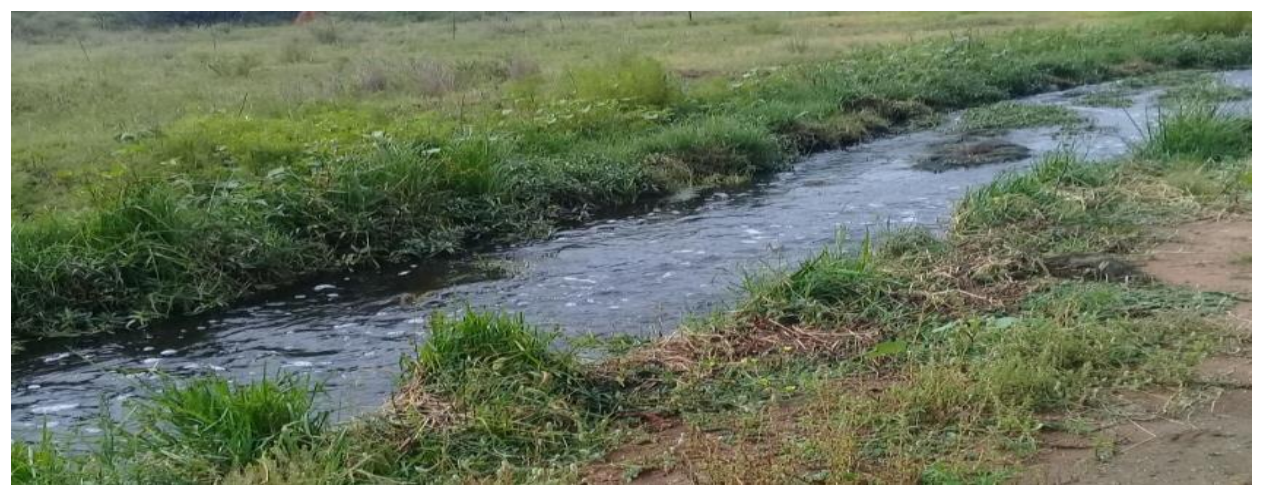

Figure 3. Livestock water source in the vicinity of resting points from where environmental samples were collected 


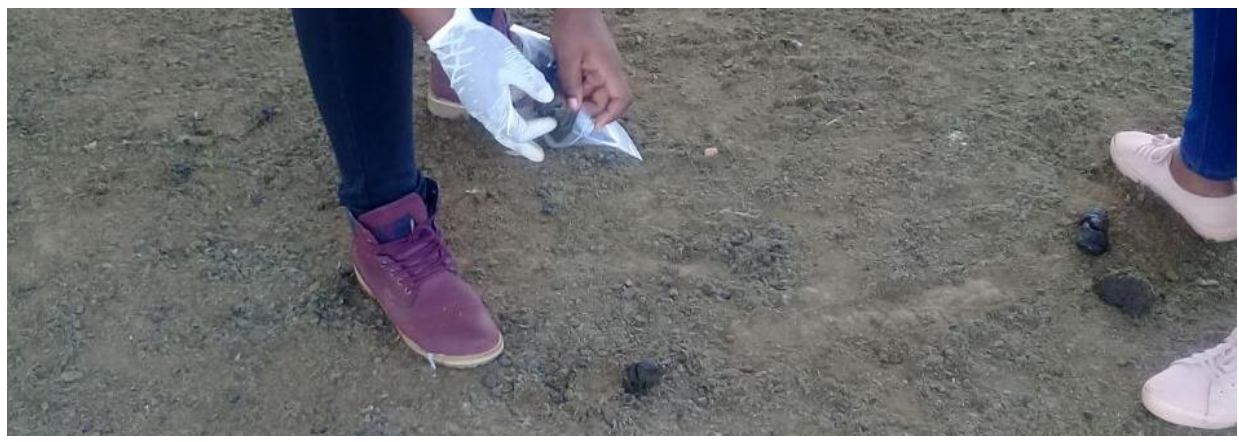

Figure 4. Collection of faecal pellets from small stock camps

\section{Collection of environmental samples}

Environmental samples (soil and faeces) analysed in this study were collected from the vicinity of sheep and goat housing facilities as well as cattle grazing pastures. Samples are collected over a period of three months, from January to March 2018. The samples were labelled according to the site of collection as cattle camp samples (CCS), sheep camp samples (SHCS) and goat camp samples (GCS). Hundred soil samples comprising of sixty CCS, twenty SHCS and twenty GCS were collected from locations that were perceived as high risk areas for bacterial contamination in a random zigzag pattern. Unpolluted and polluted top soil samples in the vicinity of faecal droppings were collected at different depths. Samples taken from below the soil surface were collected using a soil auger according to the procedure described by Brooks (2016). Seventy faecal samples comprising of thirty CCS, twenty SHCS and twenty GCS were collected. Cattle faecal samples were collected as cowpats on grazing land while sheep and goat faecal samples were collected as pellets. Approximately 100-200 g environmental samples were collected in sterile sealable plastic bags. The samples were then transported on ice, in a Styrofoam cooler box and transported to the University of Limpopo, Biotechnology Laboratory for microbial analysis

\section{Microbial analysis of environmental samples}

All the required consumables for the study were procured from Prestige Laboratories (Pty) Ltd, Durban, South Africa. Microbial analyses were performed under sterile conditions in a laminar flow with a Bunsen burner to avoid contamination from the environment. The collected samples were cultured on selective and general media for isolation of pathogenic bacteria.

Reinforced clostridia agar, Reinforced clostridia broth, sheep blood agar, anaerobic basal broth and nutrient agar were prepared and used for detailed investigation of pathogenic bacteria according to the manufacturer's instructions. Environmental samples were serially diluted to reduce the bacterial concentration of the original soil sample to levels low enough for single colonies to be grown on agar plates, allowing for calculation of the initial counts of bacteria in the environmental samples (Koch, 1883).

\section{Purification of bacteria and determination of total counts}

Bacterial culture and purification were carried out according to the methodology of Bagge et al. (2009) while colony counts were determined according to Brugger (2012) (Eq. 1). Samples cultured on sheep blood agar grew and triggered haemolyses within 
$24 \mathrm{~h}$ of incubation at $37^{\circ} \mathrm{C}$. The isolates appeared flat and raised with the shape being filamentous to irregular, round and punctiform. They were smooth or wrinkled and the colour ranged from grey, cream to white and with few colonies being yellow (Figs. 57). Different colonies subcultured on nutrient agar for purification were able to grow under anaerobic conditions within 24 to $36 \mathrm{~h}$ of incubation at $37^{\circ} \mathrm{C}$.
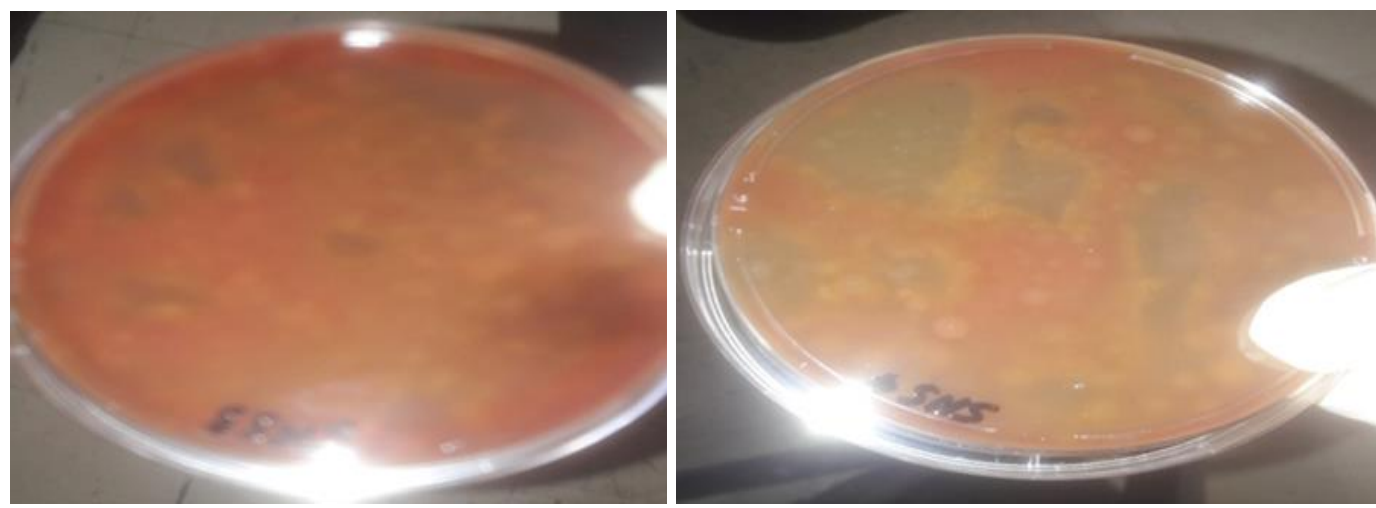

Figure 5. Plates of colonies cultured on sheep blood agar
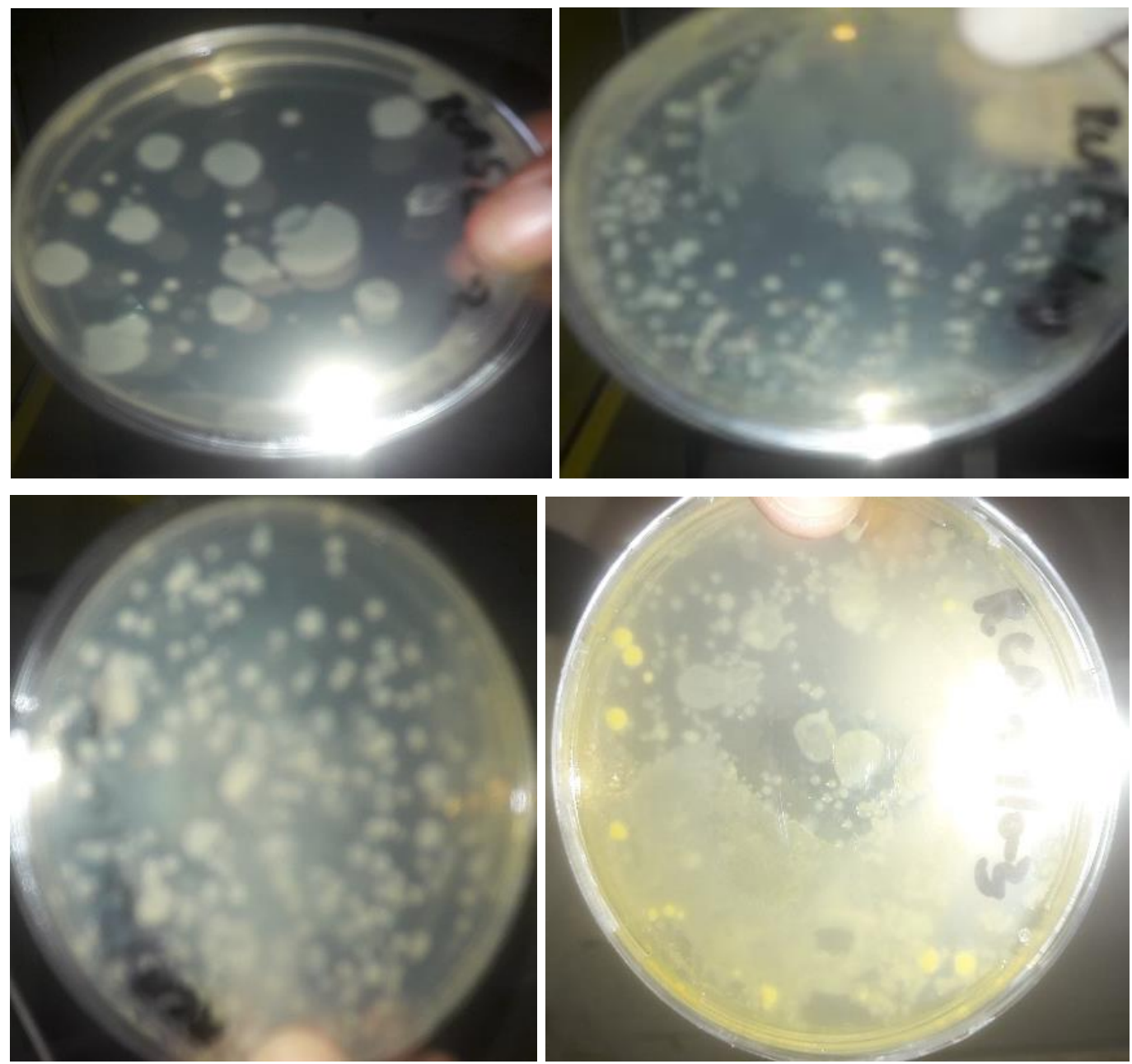

Figure 6. Plates of colonies cultured on Reinforced Clostridia and nutrient agar 

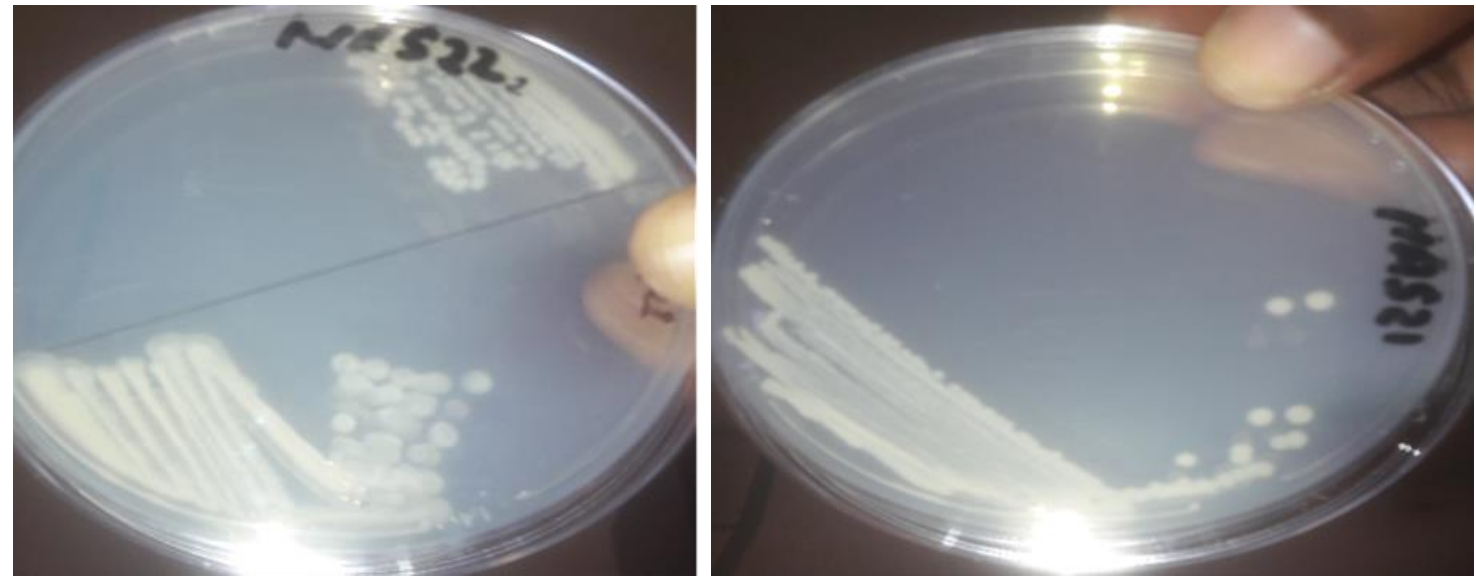

Figure 7. Plates with a four-way streaking of pure cultures on nutrient agar

\section{Proteomic identification of colonies}

All bacterial isolates reported in this study were analysed by MALDI-TOF MS, using a Microflex LT bench top mass spectrometer (Bruker Daltonics, Maldi Biotyper, Bremen, Germany). The software for the control of the instrument was FlexControl 3.3 and Maldi Biotyper 3.1 (Bruker Daltonics) for the analysis of the spectra and comparison with the database. A bacterial test standard provided by the manufacturer was included in every run for calibration purposes. Default settings (acquisition of mass spectra in the linear positive mode within the $2 \mathrm{e} 20 \mathrm{kDa}$ range, ion source 1 (IS1) $20 \mathrm{kV}$, IS2 $18.05 \mathrm{kV}$, lens $6.0 \mathrm{kV}$, linear detector 2,560 V) were applied for all the detections. A rapid, on-plate method that requires less time and reagents for its performance was followed in this study (Matsuda et al., 2012).

\section{Data presentation}

The numbers of viable bacteria per gram were obtained using a mathematical formula for colony forming units (CFU) per gram of environmental sample. Diversity, occurrence and frequency of isolation of pathogenic bacteria identified in environmental samples using MALDI-TOF MS are presented with descriptive statistics. Microsoft Excel, 2013 was used to compare the level of contamination in faecal and soil samples.

$$
\mathrm{CFU} / g=\frac{\text { Number of colonies per agar plate } \times \text { Dilution factor }}{\text { Volume of culture plated }}
$$

\section{Results}

\section{Colony forming units per gram of environmental sample}

Colony forming units were calculated using the formula of Harley (2005) (Eq. l) based on average colony counts per plate. This was done to estimate the number of viable bacteria per gram of environmental sample. All samples were of similar weight $(1 \mathrm{~g})$ and exposed to same dilution factors of $10^{-5}, 0.1 \mathrm{ml}$ of bacterial culture were plated per agar plate. Based on these calculations, there were differences in the average colony forming units of different sampling locations. The results indicated that the cattle 
camp had a higher level of contamination as compared to the goat and sheep camps for both soil and faecal samples. The highest counts were observed in samples from the cattle camp and the lowest counts were observed in samples from the sheep camp for both soil and faecal samples (Figures 5 and 6 ).

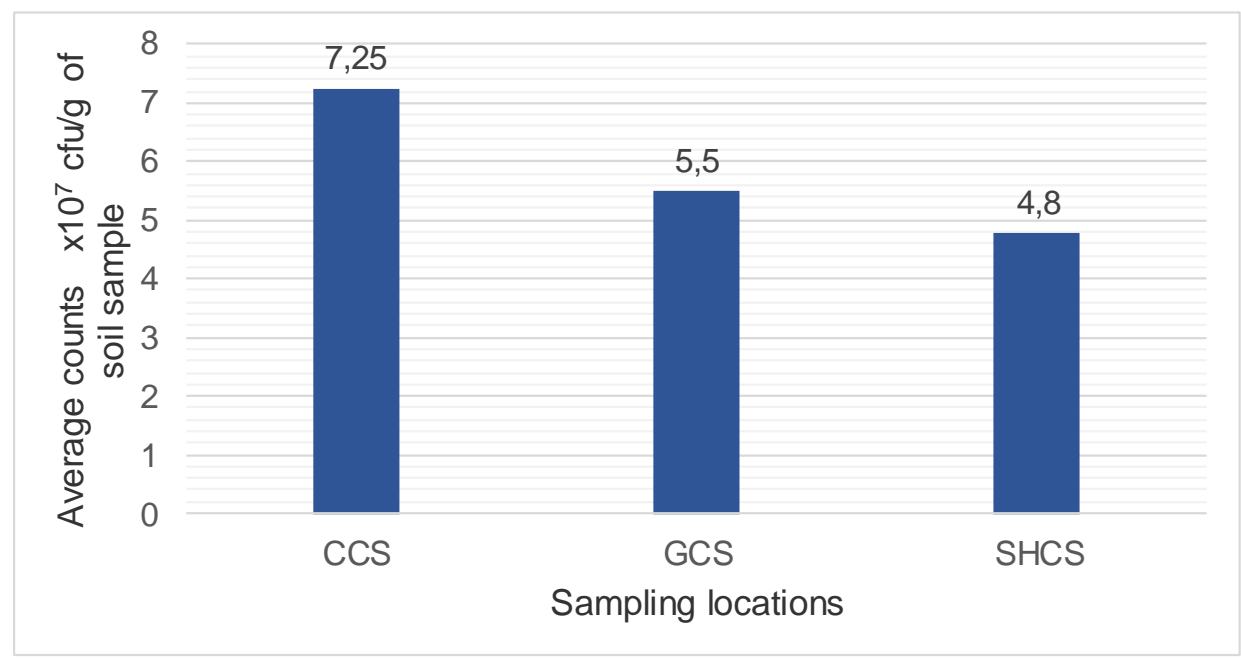

Figure 5. Average colony forming units (CFU) per gram of soil sample from different camps within the farm

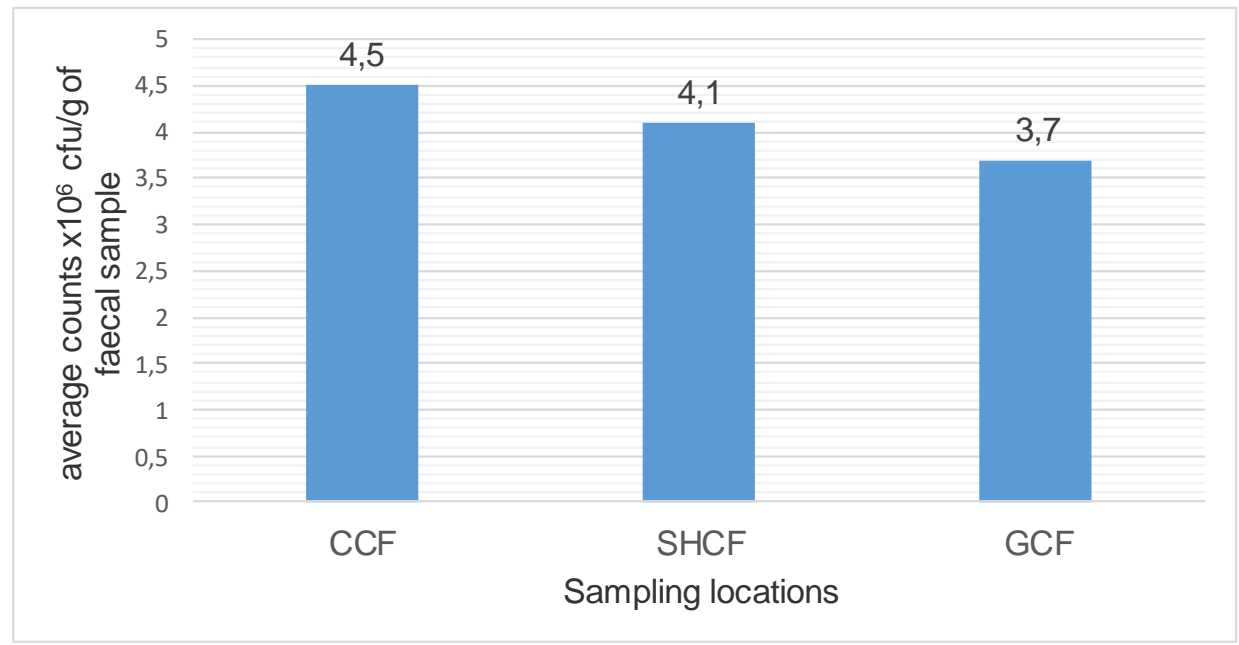

Figure 6. Average colony forming unit per gram of faecal sample from different camps in the farm

\section{Diversity of bacterial species identified in soil and faecal samples}

During the study period, a total of hundred and seventy environmental samples collected for microbial analysis of pathogenic bacteria were analysed by MALDI-TOF MS using the simplified on-plate method. Hundred and thirty-four (79\%) of the samples comprising of 108 soil and 26 faecal samples were successfully analysed and tested positive for different bacterial species. The remaining thirty-six samples $(21 \%)$ could 
not be identified by the technique used. Tables 1 and 2 indicate the bacterial isolates identified upto genus/species level for faecal and soil samples respectively. Based on these results, it was observed that different farm environments harbour different bacterial species. However, minor similarities were observed with few bacterial species where $B$. cereus and $E$. coli were isolated in both manure and faecal samples. Using (Eq. 2) Bacillus cereus were identified as the most dominant species isolated from soil samples in 36 positive samples (33\%), followed by B. mycoides in 24 positive samples (22\%) (Table 3). Regarding faecal samples, 26 samples tested positive with E. coli being the most prevalent species, identified in 9 positive samples $(34.6 \%)$, followed by Acinetobacter baumannii identified in 8 samples (30.8\%), Acinetobacter baumanii in 5 samples $(19.2 \%)$, B. cereus and B. psedomycoides were the least dominant with $(7.7 \%)$ each (Table 4).

Table 1. Bacterial species identified from faecal samples by MALDI-TOF MS using the simplified on-plate method $(n=26)$

\begin{tabular}{c|c|c|c|c|c}
\hline \multirow{2}{*}{ Bacteria species } & \multirow{2}{*}{$\begin{array}{c}\text { No of positive } \\
\text { samples }\end{array}$} & \multicolumn{4}{|c}{ Cut off values proposed for this study } \\
\cline { 3 - 6 } & 9 & $\geq \mathbf{3}$ & $\mathbf{2 . 0 0 - 2 . 9 9 9}$ & $\mathbf{1 . 6 9 9 - 1 . 9 9 9}$ & $\mathbf{0 . 0 0 - 1 . 5 9 9}$ \\
\hline Escherichia coli $^{*}$ & 2 & - & 8 & 1 & - \\
Bacillus cereus $^{*}$ & 2 & - & - & 2 & - \\
Bacillus pseudomycoides $_{\text {Acinetobacter genomospecies }}$ & 8 & - & 2 & - & 2 \\
Acinetobacter baumanii & 5 & - & 4 & 6 & - \\
\hline Total & $\mathbf{2 6}$ & $\mathbf{0}$ & $\mathbf{1 4}$ & $\mathbf{1 0}$ & $\mathbf{2}$ \\
\hline
\end{tabular}

*Pathogenic bacteria

Table 2. Bacterial species identified from soil samples by MALDI-TOF MS using the simplified on-plate method $(n=108)$

\begin{tabular}{|c|c|c|c|c|c|}
\hline \multicolumn{6}{|c|}{ Cut off values proposed for this study } \\
\hline Bacteria species & $\begin{array}{c}\text { No of positive } \\
\text { Samples }\end{array}$ & $\geq \mathbf{3}$ & 2.00-2.99 & 1.6-1.99 & 0.00-1.599 \\
\hline Bacillus cereus $^{*}$ & 36 & - & 6 & 30 & - \\
\hline Listeria monocytogens $^{*}$ & 2 & - & - & - & 2 \\
\hline Lysinibacillus fusiformis & 4 & - & - & 2 & 2 \\
\hline Bacillus megaterium & 1 & - & - & 1 & - \\
\hline Staphylococcus aureus* & 1 & - & - & 1 & - \\
\hline Enterobacter cloacae & 4 & - & - & 3 & 1 \\
\hline Enterobacter cancerogenus & 1 & - & - & - & 1 \\
\hline Bacillus simplex & 1 & - & - & 1 & - \\
\hline Enterobacter absburiae & 2 & - & - & 2 & - \\
\hline Bacillus mycoids & 24 & - & - & 20 & 4 \\
\hline Bacillus weihenstephanesis & 12 & - & - & 8 & 4 \\
\hline Escherichia coli ${ }^{*}$ & 4 & - & 3 & 1 & - \\
\hline Seratia marcescens ${ }^{*}$ & 5 & - & 2 & 2 & 1 \\
\hline Bacillus licheniformis $^{*}$ & 4 & - & - & 3 & 1 \\
\hline Bacillus endophyticus & 1 & - & - & 1 & - \\
\hline Pseudomonas resinovarans & 1 & - & - & - & 1 \\
\hline Pseudomonas aeruginosa ${ }^{*}$ & 2 & - & - & 2 & - \\
\hline Pseudomonas monteilii & 2 & - & - & 1 & 1 \\
\hline Pseudomonas corrugate & 1 & - & - & 1 & - \\
\hline Total & 108 & $\mathbf{0}$ & 11 & 79 & 18 \\
\hline
\end{tabular}

*Pathogenic bacteria 
Table 3. Occurrence and percentage frequency of bacteria from soil of different camps in the $\operatorname{farm}(n=108)$

\begin{tabular}{|c|c|c|c|c|c|c|c|c|c|c|c|}
\hline \multirow{3}{*}{ Bacterial species } & \multirow{3}{*}{$\begin{array}{c}\text { No. of } \\
\text { positive } \\
\text { samples in } \\
\text { the farm }\end{array}$} & \multirow{3}{*}{$\begin{array}{l}\text { \% frequency } \\
\text { in the farm }\end{array}$} & \multicolumn{3}{|c|}{ Occurrence } & \multicolumn{6}{|c|}{$\begin{array}{l}\text { No of positive samples in the camp and \% } \\
\text { frequency }\end{array}$} \\
\hline & & & \multirow{2}{*}{ CCS } & \multirow{2}{*}{ SHCS } & \multirow{2}{*}{ GCS } & \multicolumn{2}{|c|}{ CCS } & \multicolumn{2}{|c|}{ SHCS } & \multicolumn{2}{|c|}{ GCS } \\
\hline & & & & & & ${ }^{+} \mathrm{NSC}$ & $\% \mathrm{FC}$ & ${ }^{+} \mathrm{NSC}$ & $\% \mathrm{FC}$ & $+\mathrm{NSC}$ & $\% \mathrm{FC}$ \\
\hline Bacillus cereus ${ }^{*}$ & 36 & 33.3 & + & + & + & 20 & 28 & 6 & 50 & 10 & 41.6 \\
\hline $\begin{array}{c}\text { Listeria } \\
\text { monocytogenes }^{*}\end{array}$ & 2 & 1.9 & + & - & - & 2 & 2.8 & 0 & 0 & 0 & 0 \\
\hline $\begin{array}{l}\text { Lysinibacillus } \\
\text { fusiformis }\end{array}$ & 4 & 3.7 & - & + & + & 0 & 0 & 1 & 8.3 & 3 & 12.5 \\
\hline Bacillus megaterium & 1 & 0.9 & + & - & - & 1 & 1.4 & 0 & 0 & 0 & 0 \\
\hline $\begin{array}{c}\text { Staphylococcus } \\
\text { aureus }^{*}\end{array}$ & 1 & 0.9 & + & - & - & 1 & 1.4 & 0 & 0 & 0 & 0 \\
\hline Enterobacter cloacae & 4 & 3.7 & + & - & - & 4 & 5.6 & 0 & 0 & 0 & 0 \\
\hline $\begin{array}{l}\text { Enterobacter } \\
\text { cancerogenus }\end{array}$ & 1 & 0.9 & + & - & - & 1 & 1.4 & 0 & 0 & 0 & 0 \\
\hline Bacillus simplex & 1 & 0.9 & + & - & - & 1 & 1.4 & 0 & 0 & 0 & 0 \\
\hline $\begin{array}{c}\text { Enterobacter } \\
\text { absburiae }\end{array}$ & 2 & 1.9 & + & - & - & 2 & 2.8 & 0 & 0 & 0 & 0 \\
\hline Bacillus mycoides & 24 & 22.2 & + & - & - & 24 & 33 & 0 & 0 & 0 & 0 \\
\hline $\begin{array}{c}\text { Bacillus } \\
\text { weihenstephanesis }\end{array}$ & 12 & 11.1 & + & - & - & 12 & 17 & 0 & 0 & 0 & 0 \\
\hline Escherichia coli $^{*}$ & 4 & 3.7 & + & - & - & 4 & 5.6 & 0 & 0 & 0 & 0 \\
\hline Serratia marcescens ${ }^{*}$ & 5 & 4.6 & - & - & + & 0 & 0 & 0 & 0 & 5 & 20.8 \\
\hline Bacillus licheniformis ${ }^{*}$ & 4 & 3.7 & - & + & - & 0 & 0 & 4 & 33.3 & 0 & 0 \\
\hline Bacillus endophyticus & 1 & 0.9 & - & - & + & 0 & 0 & 0 & 0 & 1 & 4.2 \\
\hline $\begin{array}{c}\text { Pseudomonas } \\
\text { resinovarans }\end{array}$ & 1 & 0.9 & - & + & - & 0 & 0 & 1 & 8.3 & 0 & 0 \\
\hline $\begin{array}{l}\text { Pseudomonas } \\
\text { aeruginosa* }\end{array}$ & 2 & 1.9 & - & - & + & 0 & 0 & 0 & 0 & 2 & 8.3 \\
\hline $\begin{array}{c}\text { Pseudomonas } \\
\text { monteilii }\end{array}$ & 2 & 1.9 & - & - & + & 0 & 0 & 0 & 0 & 2 & 8.3 \\
\hline $\begin{array}{c}\text { Pseudomonas } \\
\text { corrugate }\end{array}$ & 1 & 0.9 & - & - & + & 0 & 0 & 0 & 0 & 1 & 4.2 \\
\hline Total & 108 & 100 & & & & 72 & 100 & 12 & 100 & 24 & 100 \\
\hline
\end{tabular}

CCS = Cattle camp soils; SHCS = Sheep camp soils; GCS = Goat camp soils; ${ }^{+}$NSC $=$Number of positive samples in camp; $\%$ $\mathrm{FC}=$ Percentage frequency in the camp; *Pathogenic bacteria; + = present; - = absent

Table 4. Occurrence and percentage frequency of bacteria from faecal samples of different camps in the farm $(n=26)$

\begin{tabular}{|c|c|c|c|c|c|c|c|c|c|c|c|}
\hline \multirow{3}{*}{ Bacteria } & \multirow{3}{*}{$\begin{array}{c}\text { No. of } \\
\text { positive } \\
\text { samples in } \\
\text { the farm }\end{array}$} & \multirow{3}{*}{$\begin{array}{l}\% \text { frequency } \\
\text { in the farm }\end{array}$} & \multicolumn{3}{|c|}{ Occurrence } & \multicolumn{6}{|c|}{$\begin{array}{l}\text { Number of positive samples in the camp and \% } \\
\text { frequency }\end{array}$} \\
\hline & & & \multirow{2}{*}{ CCF } & \multirow{2}{*}{ SHCF } & \multirow{2}{*}{ GCF } & \multicolumn{2}{|c|}{ CCF } & \multicolumn{2}{|c|}{ SHCF } & \multicolumn{2}{|c|}{ GCF } \\
\hline & & & & & & ${ }^{+} \mathrm{NSC}$ & $\% \mathrm{FC}$ & ${ }^{+} \mathrm{NSC}$ & $\% \mathrm{FC}$ & ${ }^{+} \mathrm{NSC}$ & $\% \mathrm{FC}$ \\
\hline Escherichia coli* & 9 & 34.6 & + & - & - & 9 & 64.2 & 0 & \begin{tabular}{|l|}
0 \\
\end{tabular} & 0 & 0 \\
\hline Bacillus cereus* & 2 & 7.7 & + & - & - & 2 & 14.3 & 0 & 0 & 0 & 0 \\
\hline $\begin{array}{c}\text { Bacillus } \\
\text { psedomycoides }\end{array}$ & 2 & 7.7 & + & - & - & 2 & 14.3 & 0 & 0 & 0 & 0 \\
\hline $\begin{array}{l}\text { Acinetobacter } \\
\text { baumannii }\end{array}$ & 8 & 30.8 & + & + & + & 1 & 7.1 & 3 & 100 & 4 & 44.4 \\
\hline $\begin{array}{l}\text { Acinetobacter } \\
\text { genomospecies }\end{array}$ & 5 & 19.2 & - & - & + & 0 & 0 & 0 & 0 & 5 & 55.6 \\
\hline Total & 26 & 100 & & & & 14 & 100 & 3 & 100 & 9 & 100 \\
\hline
\end{tabular}

$\mathrm{CCF}=$ Cattle camp faeces; SHCF = Sheep camp faeces; GCF = Goat camp faeces; + = Present; - = Absent; *Pathogenic bacteria;

${ }^{+} \mathrm{NSC}=$ Number of positive samples in the camp; \% FC = Percentage frequency in the camp 
In the present study, the levels of environment contamination by pathogenic bacteria varied with respect to sampling location. However, there were some similarities with respect to the bacterial isolates prevailing across sampling locations (Tables 3 and 4).

Percentage frequencies in Tables 3 and 4 were calculated using Equation 2:

$$
\% \text { Frequency }=\frac{\text { Number of samples from a camp positive for a bacterial species }}{\text { Total number of positive samples from the farm/camp }} \times 100
$$

\section{Discussion}

This study utilised MALDI-TOF MS to identify bacterial isolates from environmental samples. The results indicated that 134 (79\%) environmental samples out of the 170 collected tested positive for various bacterial species with MALDI-TOF MS identification. Urwlyer and Glaubitz (2015) reported MALDI-TOF MS to have a revolutionized speed and precision of microbial for clinical isolates to outperform conventional methods. This is evidenced in their study were MALDI-TOF MS showed the lowest number of false identification $(4 \%)$ and $60 \%$ accuracy at genus level. In contrast, the biochemical-based system assigned $25 \%$ of genera incorrectly. In this study, MALDI-TOF MS provided identification at the genus level of $67 \%$ of the bacterial isolates. This agrees with Dupont et al. (2010), Justeen et al. (2011), Nagy et al. (2012), Wieser et al. (2012), Lee et al. (2015) and Florio et al. (2018) who reported the capacity of MALDI-TOF MS to identify bacterial microorganisms at the genus and species level according to the cut of values in this study (score value $2.000-2.299$ ) ranging from 65.2 to $83.9 \%$. Average colony forming units in both soil and faecal samples fell within the range reported by previous researchers for environmental samples (Okoh et al., 1999; Ogunmwonyi et al., 2008). Total bacterial counts were relatively higher in soil samples suggesting high contaminations as compared to faecal samples.

These results agree with the reports of Trawińska et al. (2006) who indicated that soil in the vicinity of high-production farms is commonly microbial-contaminated as arable land and pastures contaminated with the faeces of sick animals, especially, contribute considerably to pathogen transfer into the soil. Boes et al. (2005) and Ngole et al. (2006) reported that micro-organisms survival in the soil environment is favoured by high temperature and moisture. Oliver et al. (2006) stated that rainfall events result in faecal microbes being washed from the cowpats into the surrounding soils where their survival could be enhanced. This finding is further supported by the results of Muirhead (2009) who reported an increase in soil E. coli concentrations on the grazed camps which they believed coincided with an increase in rainfall during their study period. Furthermore, Kress and Gifford (1984) and Stoddard et al. (1998) reported that heavy rain or irrigation on a fresh cow pat is likely to result in far greater microbial mobilization and leaching. Mobilization and leaching of bacteria during rainfall could be the reason for high percentage prevalence of bacteria species in soil compared to faecal samples recorded in the current study. Bacteria leach with water into the soil, where they incubate and multiply resulting in contamination of pastures were animals graze (Kress and Gifford, 1984).

In the present study, Bacillus species was identified to be the most prevalent species in soil samples. This is in agreement with Gutiérrez- Mañero et al. (2003) and Amin (2015), who reported bacillus as naturally occurring soil bacteria and most abundant 
genus in the rhizosphere of soil. From this genus, the most dominant species appeared to be $B$. cereus, which when allowed an opportunity to invade mammalian tissues is an opportunistic pathogen that may cause severe or local systematic infections such as endophthalmitis and septicaemia (Kotiranta et al., 2000). B. cereus has been reported to cause serious clinical diseases in farm animals, thereby causing economic loses to farmers. Songer and Post (2005), Nieminen et al. (2007) and Salih (2015) reported $B$. spp to occasionally cause mastitis in cattle. Furthermore, B. cereus has been reported as an important food borne pathogen. Tewari and Abdullah (2015) reported highly toxic strains of B. cereus responsible for food-related fatalities. Ranieri et al. (2009) and Gundogan and Avci (2014) reported Bacillus spp to be ubiquitous in nature. The ability of its spores to tolerate different environmental conditions including elevated temperatures result in these species being the most common isolated bacteria from food, air, soil, and faecal samples. However, the reports of Bavykin et al. (2004) indicating that bacillus is the most common genus in faecal samples are in contrast with the findings of this study as these bacteria tested positive only in faecal samples of cattle with a frequency occurrence of $6.6 \%$.

In faecal samples, $E$. coli was the most frequently isolated pathogen. The dominance of $E$. coli in faecal samples reported in our study agrees with reports by previous researchers (Tahamtan et al., 2006; Raji et al., 2006; Hiko et al., 2008; Hashemi et al., 2010). Hogan et al. (1999) and Abakpa et al. (2015) reported E. coli to be naturally present in faeces of warm blooded animals. E. coli occurrence has been previously used as an indicator of faecal contamination, signaling the possible presence of faecal pathogens such as Salmonella and Shigella species (Odonkor and Addo, 2018). In a study by Rodrigues et al. (2015), MALDI TOF-MS identified $83 \%$ E. coli prevalence in faecal samples, however, the pathogenicity of the strains were not reported. Schmidt et al. (2015) reported $E$. coli to be free-living commensals in animal intestines. The prevalence of this bacterial species was found to be high in the cattle camp in comparison with the small stock camps. Sima et al. (2009), Kiranmayi et al. (2010) and Rahimi et al. (2012) reported domestic animals as the sources of E. coli. However, the major animal carriers seem to be healthy domesticated ruminants, primarily cattle and, to a lesser extent sheep.

These findings agree with the results of our study as E. coli were only identified in cattle faeces with zero prevalence in sheep and goat faecal samples. However, large variations have been described in the shedding patterns of individual animals, the proportion of shedding animals on farms that harbor them and, over time, in the amount of shedding on the same farm (Smith et al., 2010). Among cattle, shedding occurs intermittently (Hancock et al., 1997; Kulow et al., 2012; Sharma et al., 2012), and it was reported that, at any time, up to $50 \%$ of the healthy animals excrete E. coli in their stool (Lim et al., 2010). Freshly deposited faeces contain the nutrients required by bacteria, and replication presumably depends on the faeces retaining water and attaining suitable temperatures for growth. Cow pats are able to retain moisture when exposed to sunlight. The pats quickly form a skin, which thickens to a well-defined crust within $48 \mathrm{~h}$ favouring bacterial growth (Van Kessel et al., 2007). However, exposure of sheep and goat pellets to the sun results in drying of the pellets due to size and less moisture contained making the environment unfavourable for bacterial growth. Topp et al. (2003) studied the relationship between soil moisture content and prevalence of E. coli bacteria and concluded that elevated soil moisture levels were associated with increased number of bacteria in the soil. This could explain the low counts of E. coli in soil samples of the 
current study as soil samples were collected in early summer where moisture content in soil is believed to be relatively low. Of the twenty-two bacterial isolates isolated from the environmental samples in this study, some species have been reported previously to carry virulent strains which are responsible for livestock infections particularly in cattle, sheep and goats. These pathogenic bacteria include: E. coli (Olson, 2001; Chekabab et al., 2013), B. cereus (Nieminen, 2007; Manyi-Loh, 2016; Robert et al., 2017), L. monocytogens (Nightingale et al., 2004; Nicholson et al., 2005), Staphylococcus aereus (Toroitich, 2013), Pseudomonas aeruginosa (Radostits et al., 2000), Seratia marcescens and B. licheniformis (Olson, 2001).

Pathogenic bacteria in farm environments pose a major epidemiological threat (Amin et al., 2013). Although E. coli have been reported as harmless commensals of the intestines of warm blooded animals, the strain E. coli $\mathrm{O} 157: \mathrm{H} 7$ has been reported to be harmful (Titilawo et al., 2015). Shearer et al. (2003) reported E. coli as one of the major bacterial pathogens associated with livestock infections in farms. Healthy colonized cattle and other ruminants are the most significant animal reservoir harboring $E$. coli (Ferens and Hovde, 2011). Previous studies linked approximately $75 \%$ of the human $E$. coli outbreaks to food products of bovine origin (Callaway et al., 2009; Munns et al., 2016). Other reservoirs that may impact transmission include sheep (La Ragione et al., 2012; Soderlund et al., 2012; Gencay, 2014), goats Pao et al.(2005), La Ragione et al.(2009), Mersha et al.(2010), Alvarez-Suarez et al.(2016) and Swift et al.(2017).

According to Tomita and Hart (2001) E coli bacteria possess several pathogenic factors responsible for their pathogenicity, among which exotoxin A (toxA) and exoenzyme $\mathrm{S}(\operatorname{exoS})$ are the two major fatal toxins which are associated with subclinical mastitis infection in bovines (Toroitich, 2013) in a cross-sectional study to determine the prevalence of mastitis and identify the associated risk factors reported the most predominantly isolated bacterium to be Staphylococcus aureus with a prevalence of $36 \%$ followed by E. coli with a prevalence of $27.2 \%$ and Pseudomonas were least isolated with less than $1 \%$ prevalence.

In the present study, L. monocytogenes tested positive in cattle camp soils (4.4\%). This falls in the same range as the findings of Mohammed et al. (2009) (5.4\%) and less compared to the findings from previous studies by Moshtaghi et al. (2003) (17.7\%) and Nightingale et al. (2004) (22.2\%) and Locatelli et al. (2013) (38.1\%). Several animal derived L. monocytogenes-contaminated food products, including raw milk, pasteurized milk, chocolate milk, butter, soft cheeses, and processed meat and poultry products, have been implicated as sources of human listeriosis cases and outbreaks (Buchanan et al., 2017). It has been reported that manure from infected or shedding animals represent direct links between human infections and L. monocytogenes in farm animals and farm environments as a result of consuming animal-derived food products that are not processed before consumption such as raw milk and raw foods of plant origin (Nightingale et al., 2004).

Previous studies reported Campylobacter species and Clostridium species to be pathogenic bacteria of livestock commonly isolated from environmental samples (Baserisalehi et al., 2007; Bagge, 2009). However, in the present study, all samples tested negative for Campylobacter species. Clostridium species were detected in 2 samples (5\%). Bandelj et al. (2016) reported a 10\% prevalence of clostridium difficile in cattle faecal samples. The use of selective media may have disadvantaged growth of other bacteria species in the samples. Olson (2001), reported the Campylobacter genus to have fastidious growth requirements making conventional detection and 
identification difficult. This could be the reason why all samples in the present study tested negative for Campylobacter species. The differences in bacterial contamination in the sampling locations in this study may be due to different management practices in the livestock camps were cattle are kept in their camp continuously resulting in piling of faecal samples increasing microbial habitat. In comparison with sheep and goats which are housed at night resulting in few fresh pellets in their camps. Spiehs and Goyal (2007), Hutchison et al. (2005) and Manyi-Loh et al. (2016) indicated that the levels and types of pathogens occurring in livestock faeces vary with animal species, dietary sources, health status and age of the animal.

\section{Conclusions and recommendations}

This study showed that diverse bacterial species contaminate the livestock grazing environment at the study farm. Although samples were collected from different locations within the farm, the bacteria isolated from soil samples were generally similar. However, with regard to faecal samples, bacterial isolates differed from one camp to the other entailing that different livestock harbour different bacteria in their faeces. Of the bacterial species isolated in the study, some genus have been reported to be highly pathogenic. This study demostrated contamination by opportunistic, food-borne bacteria like B. cereus and L. monocytogenes in the farm environment and the need for good hygiene practices to prevent its entry into the food chain. Rapid microbial identification is necessary for quick implementation of relevant disease management strategies at farms. The findings of this study show that MALDI-TO MS can identify bacteria rapidly in environmental samples. This method can be used to identify potential disease risk in an environment and allow for appropriate control measures.

\section{REFERENCES}

[1] Abakpaa, G. O., Umoha, V. J., Ameha, J. B., Yakubua, S. E., Ibekweb, A. M. (2015): Prevalence and antimicrobial susceptibility of pathogenic Escherichia coli O157 in fresh produce obtained from irrigated fields. - Environmental Technology and Innovation 4: 17.

[2] Adak, G. K., Long, S. M., O’Brien, S. J. (2002): Trends in indigenous food borne disease and deaths, England and Wales: 1992 to 2000. - Gut 51: 832-841.

[3] Adl, S., Iron, D., Kolokolnikov, T. A. (2011): Threshold area ratio of organic to conventional agriculture causes recurrent pathogen outbreaks in organic agriculture. Science of the Total Environment 409: 2192-2197.

[4] Aitken, M. D., Sobsey, M. D., Shehee, M., Blauth, K. E., Hill, V. R., Farrell, J. B., Nappier, S. P., Walters, G. W. (2005): Laboratory evaluation of thermophilic anaerobic digestion to produce Class A biosolids. 2. Inactivation of pathogens and indicator organisms in a continuous-flow reactor followed by batch treatment. - Water Environment Research 77: 3028-3036.

[5] Alvarez-Suarez, M. E., Otero, A., Garcia-Lopez, M. L., Dahbi, G., Blanco, M., Mora, A., Blanco, J. (2016): Genetic characterization of Shiga toxin-producing Escherichia coli (STEC) and atypical enteropathogenic Escherichia coli (EPEC) isolates from goat's milk and goat farm environment. - International Journal of Food Microbiology 236: 148-54.

[6] Amin, M. M. G., Forslund, A., Bui, X. T., Juhler, R. K., Petersen, S. O., Laegsmand, M. (2013): Persistence and leaching potential of microorganisms and mineral $\mathrm{N}$ in animal 
manure applied to intact soil columns. - Applied and Environmental Microbiology 79: 535-542.

[7] Amin, I. M., Rakhisi, Z., Zarei, A. (2015): Isolation and identification of bacillus species from soil and evaluation of their antibacterial properties. - Avicenna Journal of Clinical Microbiology Infection 2(1): 23233.

[8] Bagge, E. (2009): Hygiene aspects of the biogas process with emphasis on spore forming bacteria. - Ph. D. Thesis, Swedish University of Agricultural Sciences, Uppsala, Sweden.

[9] Bagge, E., Persson, M., Johansson, K. E. (2010): Diversity of spore-forming bacteria in cattle manure, slaughterhouse waste and samples from biogas plants. - Journal of Applied Microbiology 5: 43.

[10] Bandelj, P., Blagus, R., Briski, F., Frlic, O., Rataj, A. V., Rupnik, M., Ocepek, M., and Vengust, M. (2016): Identification of risk factors influencing Clostridium difficile prevalence in middle-size dairy farms. - Veterinary Research 47: 41.

[11] Baserisalehi, M., Bahador, N., Kapadnis, B. P. (2007): Isolation and characterization of Campylobacter spp. from domestic animals and poultry in south of Iran. - Pakistan Journal of Biological Sciences 10(9): 1519-1524.

[12] Bavykin, S. G., Lysov, Y. P., Zakhariev, V. (2004): Use of 16S rRNA, 23S rRNA, and gyrB gene sequence analysis to determine phylogenetic relationships of Bacillus cereus group microorganisms. - Journal of Clinical Microbiology 42: 3711-3730.

[13] Becker, S. (2015): The communal idea in the 21st century. - Contemporary Sociology: A Journal of Reviews 44(3): 342-344.

[14] Boes, J., Alban, L., Bagger, J., Møgelmose, V., Baggesen, D. L., Olsen, J. E. (2005): Survival of Escherichia coli and Salmonella typhimurium in slurry applied to clay soil on Danish swine farm. - Preventive Veterinary Medicine 69: 213-228.

[15] Brinton, W. F., Storms, P., Blewett, T. C. (2009): Occurrence and levels of fecal indicators and pathogenic bacteria in market-ready recycled organic matter composts. Journal of Food Protection 72: 332-339.

[16] Brooks, J. (2016): Soil Sampling for Microbial Analyses, Manual of Environmental Microbiology, Fourth Edition. - ASM Press, Washington, DC.

[17] Brugger, S. D., Baumberger, C., Jost, M., Jenni, W., Brugger, U. (2012): Automated counting of bacterial colony forming units on agar plates. - PLoS ONE 7(3): 6.

[18] Buchanan, R. L., Gorris, L. G., Hayman, M. M., Jackson, T. C., Whiting, R. C. (2017): A review of Listeria monocytogenes: an update on outbreaks, virulence, dose-response, ecology, and risk assessments. - Food Control 75: 1-13.

[19] Callaway, T. R., Edrington, T. S., Nisbet, D. J. (2014): Meat Science and Muscle Biology Symposium: Ecological and dietary impactors of food borne pathogens and methods to reduce fecal shedding in cattle. - Journal of Animal Sciences 92: 1356-1365.

[20] Cantor, M., Pires, M. M., Marquitti, F. M., Raimundo, R. L., Sebastián-González, E., Coltri, P. P., et al. (2017): Nestedness across biological scales. - PLoS One 12(2).

[21] Chauret, C., Springthorpe, S., Sattar, S. (1999): Fate of Cryptosporidium oocysts, Giardia oocysts and microbial indicators during wastewater treatment and anaerobic sludge digestion. - Canadian Journal of Microbiology 45: 257-262.

[22] Chekabab, S. M., Paquin-Veillette, J., Dozois, C. M., Harel, J. (2013): The ecological habitat and transmission of Escherichia coli O157: H7. - FEMS Microbiology Letters 341: 1-12.

[23] Christiansson, A., Bertilsson, J., Svensson, B. (1999): Bacillus cereus spores in raw milk: Factors affecting the contamination of milk during the grazing period. - Journal of Dairy Science 82: 305-314.

[24] Cooper, B. J., Valentine, B. A. (2016): Muscle and Tendon. - In: Maxie, M. G. (ed.) Jubb, Kennedy, and Palmer's Pathology of Domestic Animals. 6th Ed. Vol. 1. Elsevier, St. Louis, MO, pp. 230-233. 
[25] Czekalski, N., Berthold, T., Caucci, S., Egli, A., Buergmann, H. (2012): Increased levels of multi resistant bacteria and resistance genes after wastewater treatment and their dissemination into Lake Geneva, Switzerland. - Frontiers in Microbiology 3: 106.

[26] Dantas-Torres, F., Chomel, B. B., Otranto, D. (2012): Ticks and tick-borne diseases: a One Health perspective. - Trends Parasito 28: 437-46.

[27] Dapilly, N., Neyrat, A. (1999): Etude des microorganismes pathogènes dans les composts. - Rapport de Recherche Bibliographique, CREED.

[28] Day, M. J. (2011) One health: the importance of companion animal vector-borne diseases. - Parasit Vectors 4: 49.

[29] Destoumieux-Garzón, D., Mavingui, P., Boetsch, G., Boissier, J., Darriet, F., Duboz P., Fritsch, C., Giraudoux, P., Le Roux, F., Morand, S., Paillard, C., Pontier, D., Sueur, C., and Voituron, Y. (2018): The one health concept: 10 years old and a long road ahead. Frontiers in Veterinary Science 5(14). DOI: 10.3389/fvets.2018.00014.

[30] Dharmasena, M., Jiang, X. 2(018): Isolation of toxigenic Clostridium difficile from animal manure and composts being used as biological soil amendments. - Applied and Environmental Microbiology 84(16).

[31] Douglas, R., Calla, B., Monica, K., Boruckia, C., Frank, J. (2003): Loged Detection of bacterial pathogens in environmental samples using DNA microarrays. - Journal of Microbiological Methods 53: 235-243.

[32] Dupont, C., Sivadon-Tardy, V., Bille, E., Dauphin, B., Beretti, J. L., A. S. Alvarez, A. S., Degand, N., Ferroni, A., Rottman, M., Herrmann, J. L., Nassif, X., Ronco, E., Carbonnelle, E. (2010): Identification of clinical coagulase-negative staphylococci, isolated in microbiology laboratories, by matrix-assisted laser desorption/ ionization-time of flight mass spectrometry and two automated systems. - Clinical Microbiology and Infection 16: 998-1004.

[33] FAO, OIE, WHO (2007): The Global Strategy for Prevention and Control of H5N1 Highly Pathogenic Avian Influenza. - FAO, Rome.

[34] Ferens, W. A., Hovde, C. J. (2011): Escherichia coli O157:H7: animal reservoir and sources of human infection. - Food Borne Pathological Diseases 8: 465-87.

[35] Florio, W., Tavanti, A., Barnini, Ghelardi, E., Lupetti, A. (2018): Recent advances and ongoing challenges in the diagnosis of microbial infections by MALDI-TOF Mass Spectrometry. - Frontiers in Microbiology 9: 1097.

[36] Gale, P. (2004): Risks to farm animals from pathogens in composted catering waste containing meat. - Veterinary Record 155: 77-82.

[37] Gencay, Y. E. (2014): Sheep as an important source of E. coli O157/O157:H7 in Turkey. - Veterinary Microbiology 172: 590-595.

[38] Gibbs, E. P. (2005): Emerging zoonotic epidemics in the interconnected global community. - Veterinary Record 157: 673-679.

[39] Godwin, D., Moore, J. A. (1997): Manure Management in Small Farm Livestock Operations. - Oregon State University Extension Service, Corvallis, OR, USA.

[40] Gundogan, N., Avci, E. (2014): Occurrence and antibiotic resistance of Escherichia coli, Staphylococcus aureus and Bacillus cereus in raw milk and dairy products in Turkey. International Journal of Dairy Technology 67(4): 562-569.

[41] Gutiérrez Mañero, F. J., Probanza, A., Ramos, B., Colón Flores, J. J., Lucas García, J. A. (2003): Ecology, genetic diversity and screening strategies of plant growth promoting rhizobacteria (PGPR). - Journal of Plant Nutrition 26(5): 1101-1115.

[42] Hancock, D. D., Besser, T. E., Rice, D. H., Herriot, D. E., Tarr, P. I. (1997): A longitudinal study of Escherichia coli O157 in fourteen cattle herds. - Epidemiology Infectious 118: 193-195.

[43] Harley, J. P., Prescott, L. M. (2005): Laboratory Exercise in Microbiology. 6th Ed. McGraw-Hill, New York. 
[44] Hashemi, M., Khanzadi, S., and Jamshadi, A. (2010): Identification of Escherchia coli O157:H7 isolated from cattle carcasses in Mashhad abattoir by Multiplex PCR. - World Applied Sciences Journal 6: 703-708.

[45] Hiko, A., Asrat, D., Zewde, G. (2008): Occurrence of Escherichia coli O157:H7 in retail raw meat products in Ethiopia. - Journal of Infection in Developing Countries 2: 389393.

[46] Hogan, J. S., Bogacz, V. L., Aslam, M., Smith, K. L. (1999): Efficacy of an Escherichia coli J5 bacterin administered to primigravid primiparous cows. - Journal of Dairy Science 82: 939-943.

[47] Hutchison, M. L., Walters, L. D., Avery, S. M., Munro, F., Moore, A. (2005): Analyses of livestock production, waste storage and pathogen levels and prevalences in farm manures. - Applied and Environmental Microbiology 71: 1231-1236.

[48] Jenjezwa, V. R., Seethal, C. E. P. (2014): The role of the state in stock farming in rural areas: A case study of Hertzog, Eastern Cape, South Africa. - Journal of the South African Veterinary Association 85(1): 7.

[49] Justesen, U. S., Holm, A., Knudsen, E., Andersen, L. B., Jensen, T. G., Kemp, M., Skov, M. N., Gahrn-Hansen, B., Møller, J. K. (2011): Species identification of clinical isolates of anaerobic bacteria: a comparison of two matrix-assisted laser desorption ionizationtime of flight mass spectrometry systems. - Journal of Clinical Microbiology 49: 43144318.

[50] Kim, J., Shepherd, M., Jiang, X. (2009): Evaluating the effect of environmental factors on pathogen regrowth in compost extract. - Microbial Ecology 58: 498-508.

[51] King, D. A., Peckham, C., Waage, J. K., Brownlie, J., Woolhouse, M. E. (2006): Epidemiology. Infectious diseases: preparing for the future. - Science 313: 1392-1393.

[52] Kiranmayi, C. B., Krishnaiah, N., Mallika, E. N. (2010): Escherichia coli O157:H7 - An emerging pathogen in foods of animal origin. - Veterinary World 3: 382-389.

[53] Koch, R. (1883): Über die neuen Untersuchungsmethoden zum Nachweis der Mikrokosmen in Boden, Luft und Wasser. - Vortrag auf dem XI. Deutschen Ärztetag in Berlin. - Vereinsblatt für Deutschland 137: 274-284.

[54] Kotiranta, A., Lounatmaa, K., Haapasalo, M. (2000): Epidemiology and pathogenesis of Bacillus cereus infections. - Microbes Infection 2: 189-198.

[55] Kress, M., Gifford, G. F. (1984): Faecal coliform release from cattle fecal deposits. Water Resources Bulletin 20: 61-66.

[56] Kulow, M. J., Gonzales, T. K., Pertzborn, K. M., Dahm, J., Miller, B. A., Park, D., Gautam, R., Kaspar, C. W., Ivanek, R., Döpfer, D. (2012): Differences in colonization and shedding patterns after oral challenge of cattle with three Escherichia coli O157:H7 strains. - Applied Environmental Microbiology 78: 8045-8055.

[57] La Ragione, R. M., Best, A,. Woodward, M. J., Wales, A. D. (2009): Escherichia coli O157:H7 colonization in small domestic ruminants. - FEMS Microbiol Rev 33: 394-410.

[58] Lange, M., Neubauer, H., Seyboldt, C. (2010): Development and validation of a multiplex real-time PCR for detection of Clostridium chauvoei and Clostridium septicum. - Molecular and Cellular Probes 24: 204-210.

[59] Lee, W., Kim, M., Yong, D., Jeong, S. H., Lee, K., Chong, Y. (2015): Evaluation of VITEK mass spectrometry (MS), a matrix-assisted laser desorption ionization time-of flight MS system for identification of anaerobic bacteria. - Annals of Laboratory Medicine 35(1): 69-75.

[60] Lim, J. Y., Li, J., Sheng, H., Besser, T. E., Potter, K., Hovde, C. J. (2007): Escherichia coli $0157: H 7$ colonization at the rectoanal junction of long-duration culture-positive cattle. - Applied Environmental Microbiology 73: 1380-1382.

[61] Locatelli, A., Depret, G., Jolivet, C., Henry, S., Dequiedt, S., Piveteau, P., Hartmann, A. (2013): Nation-wide study of the occurrence of Listeria monocytogenes in Frenchsoilsusingculture-based andmoleculardetection methods. - Journal of Microbiolical Methods 93: 242-250. 
[62] Maas, J. (2012): Clostridial vaccines: why we use them. - UCD Vet Views - California Cattleman 2002(June): 12-13.

[63] Madziga, I. I., Alawa, C. B. I., Lamidi, O. S., Goska, D. Y., Adesote, A. A. (2013): Feedlot assessment of four indigenous Breeds of Cattle in Nigeria. - International Journal Sciences and Medical Research 1(3): 35-38.

[64] Manyi-Loh, C. E., Mamphweli, S. N., Meyer, E. L., Makaka, G., Simpson, M., Okoh, A. I. (2016): An overview of the control of bacterial pathogens in cattle manure. International Journal of Environmental Research and Public Health 13(9): 843. DOI: 10.3390/ijerph13090843.

[65] Matsuda, N., Matsuda, M., Notake, S., Yokokawa, H., Kawamura, Y., Hiramatsu, K., Kikuchia, K. (2012): Evaluation of a simple protein extraction method for species identification of clinically relevant staphylococci by matrix-assisted laser desorption ionization time of flight mass spectrometry. - Journal of Clinical Microbiology 50: 38623866.

[66] McGuirk, S. M. (2015): Managing Clostridia Diseases in Cattle. - PhD Thesis. University of Wisconsin, School of Veterinary Medicine.

[67] Meissner, H. H., Scholtz, M. M., Palmer, A. R. (2013): Sustainability of the South African livestock sector towards 20150 Part 1: Worth and impact of the sector. - South African Journal of Animal Science 3: 43.

[68] Mencke, N. (2013): Future challenges for parasitology: vector control and "One health" in Europe: the veterinary medicinal view on CVBDs such as tick borreliosis, rickettsiosis and canine leishmaniosis. - Veterinary Parasitology 195: 256-271.

[69] Mersha, G., Asrat, D., Zewde, B., Kyule, M. (2010): Occurrence of Escherichia coli O157:H7 in faeces, skin and carcasses from sheep and goats in Ethiopia. - Letters in Applied Microbiology 50: 71-6.

[70] Mohammed, H. O., Stipetic, K., McDonough, P. L., Gonzalez, R. N., Nydam, D. V., Atwill, E. R. (2009): Identification of potential on-farm sources of Listeria monocytogenes in herds of dairy cattle. - American Journal of Veterinary Research 70: 383-388.

[71] Morand S, Lajaunie, C. (2017): Biodiversity and Health. Linking Life, Ecosystems and Societies. - Elsevier, ISTE Press, London.

[72] Morand, S., Figuié, M. (2016): Émergence de maladies infectieuses. Risques et enjeux de société. - Quae, Versailles.

[73] Moshtaghi, H., Garg, S. R., Mandokhot, U. V. (2003): Prevalence of Listeria in soil. Indian Journal of Experimental Biology 41: 1466-1468.

[74] Muirhead, R. W. (2009): Soil and faecal material reservoirs of Escherichia coli in a grazed pasture. - New Zealand Journal of Agricultural Research 52(1): 1-8.

[75] Munns, K. D., Zaheer R, Xu, Y., Stanford, K., Laing, C. R., Gannon, V. P. J., Selinger, L. B., McAllister, T. A. (2016): Comparative genomic analysis of Escherichia coli O157:H7 isolated from super-shedder and low-shedder cattle. - PLoS One 11: e0151673.

[76] Nageswaran, N., Ramteke, P. W., Verma, O. P., Pande, A. (2012): Antibiotic susceptibility and heavy metal tolerance pattern of Serratia marcescens isolated from soil and water. - Journal of Bioremediation and Biodegradation 3: 158.

[77] Nagy, E. S., Becker, M., Kostrzewa, N., Barta, E., Urban, E. (2012): The value of MALDI-TOF MS MS for the identification of clinically relevant anaerobic bacteria in routine laboratories. - Journal of Medical Microbiology 61(10): 1393-1400.

[78] Neumann, C., Harris, D. M., Rogers, L. M. (2002): Contribution of animal source foods in improving diet quality and function in children in the developing world. - Nutritional Research 22(1): 193-220.

[79] Ngole, V., Mpuchane, S., Totolo, O. (2006): Survival of faecal coliforms in four different types of sludge - amended soils in Botswana. - European Journal of Soil Science 42: 208218. 
[80] Nicholson, F. A., Groves, S. J., Chambers, B. J. (2005): Pathogen survival during livestock manure storage and following land application. - Bioresources Technology 96: 135-143.

[81] Nieminen, T., Rintaluoma, N., Andersson, M., Taimisto, A. M., Ali-Vehmas, T., Seppa"la, A., Priha, O., Salkinoja-Salonen, M. (2007): Toxinogenic Bacillus pumilus and Bacillus licheniformis from mastitis milk. - Veterinary Microbiology 124: 329-339.

[82] Nightingale, K. K., Schukken, Y. H., Nightingale, C. R., Fortes, E. D., Ho, A. J., Her, Z., Grohn, Y. T., McDonough, P. L., Wiedmann, M. (2004): Ecology of transmission of Listeria monocytogenes infecting ruminants and in the farm environment. - Applied Environmental Microbiology 70: 4458-4467.

[83] Nishteswar, K. (2014): Cultivation, Collection and Endangered Status of Medicinal Plants - Ancient and Modern Perspectives: Conservation, Cultivation and Exploration of Therapeutic Potential of Medicinal Plants. - CCRAS, Dept. of AYUSH, Govt. of India, New Delhi, pp. 189-218.

[84] Odonkor, S. T., Addo, K. K. (2018): Prevalence of multidrug-resistant Escherichia coli isolated from drinking water sources. - International Journal of Microbiology 7204013.

[85] Ogunmwonyi, I. N., Igbinosa, O. E., Aiyegoro, O. A., Odjadjare, E. E. (2008): Microbial analysis of different top soil samples of selected site in Obafemi Awolowo University of Nigeria. - Academic Journals 3:(3) 120-124.

[86] Okoh, L. A., Badejo, M. A., Nathaniesl, I. T., Tian, G. (1999): Studies on the bacteria, fungi and springtails (collembola) of an agroforestry arboretum in Nigeria. - Pedobio 43: 18-27.

[87] Oliver, D. M., Haygarth, P. M., Clegg, C. D., Heathwaite, A. L. (2006): Differential E. coli die-off patterns associated with agricultural matrices. - Environmental Science and Technology 40: 5710-5716.

[88] Olson, M. E. (2001): Human and Animal Pathogens. - In: Olson, M. E. (ed.) Microbiology and Infectious Diseases. University of Calgary, Calgary, AB, Canada.

[89] Pachepsky, Y. A., Sadeghi, A. M., Bradford, S. A., Shelton, D. R., Guber, A. K., Dao, T. (2006): Transport and fate of manure-based pathogens: Modelling perspective. Agricultura Water Management 86: 81-92.

[90] Pao, S., Patel, D., Kalantari, Tritschler, J. P., Wildeus, S., Sayre, B. L. (2005): Detection of Salmonella strains and Escherichia coli O157:H7 in feces of small ruminants and their isolation with various media. - Applied Environmental 71: 2158-61.

[91] Park, E., Lee, C., Bisesi, M., Lee, J. (2014): Efficiency of peracetic acid in inactivating bacteria, viruses, and spores in water determined with ATP bioluminescence, quantitative PCR, and culture-based methods. - Journal of Water Health 12: 13-23.

[92] Pell, A. N. (1997): Manure and microbes: Public and animal health problem. - Journal of Dairy Science 80: 2673-2681.

[93] Plaut, A. G. (2000): Clinical pathology of food borne diseases: notes on the patient with food borne gastrointestinal illness. - Journal of Food Protection 63: 822-826.

[94] Radostits, O. M., Gay, C. C., Blood, D. C., Hinchcliff, K. W. (2000): Bovine Mastitis. In: Radostits, O. M. (ed.) Veterinary Medicine. A Textbook of the Diseases of Cattle, Sheep, Pigs, Goats and Horses. 9th Ed. W B Saunders Co., Philadelphia, USA, pp. 603612.

[95] Rahimi, E., Kazemeini, H. R., Salajegheh, M. (2012): Escherichia coli O157:H7/NM prevalence in raw beef, camel, sheep, goat, and water buffalo meat in Fars and Khuzestan provinces, Iran. - Veterinary Research Forum 3: 13 -17.

[96] Raji, M., Minga, U., Machangu, R. (2006): Current epidemiological status of enterohaemorrhagic Escherichia coli O157:H7 in Africa. - Chinese Medical Journal 119: 217-222.

[97] Ranieri, M. L., Huck, J. R., Sonnen, M., Barbano, D. M., Boor, K. J. (2009): High temperature, short time pasteurization temperatures inversely affect bacterial numbers 
during refrigerated storage of pasteurized milk. - Journal of Dairy Science 92: 48234832.

[98] Robert, L. B., Leon, G. M., Gorris, M. M., Melinda, M. H., Timothy, C. J., Richard, C. W. (2017): A review of Listeria monocytogenes: An update on outbreaks, virulence, dose-response, ecology, and risk assessments. - Food Control 75: 1-13.

[99] Salih, R. R. M. (2015): Comparison between the percentage of incidence of mastitis caused by bacillus spp. and staphylococcus spp. in winter season in Khartoum state. Sudan Online Journal of Animal and Feed Research 5(4): 112-116.

[100] Salihu, M. D., Junaidu, A. U., Oboegbulem, S. I., Egwu, G. O., Tambuwal, F. M., Yakubu, Y. (2009): Prevalence of Campylobacter species in apparently healthy goats in Sokoto State (Northwestern) Nigeria. - African Journal of Microbiology Research 3(9): $572-574$.

[101] Schmidt, V. M., Pinchbeck, G. L., Nuttall, T., McEwan, N., Dawson, S., Williams, N. J. (2015): Antimicrobial resistance risk factors and charaterisation of faecal E. coli isolated from healthy Labrador retrievers in the United Kingdom. - Preventive Veterinary Medicine 119: 31-40.

[102] Sharma, V. K., Sacco, R. E., Kunkle, R. A., Bearson, S. M. D., Palmquist, D. E. (2012): Correlating levels of type III secretion and secreted proteins with fecal shedding of Escherichia coli O157:H7 in cattle. - Infection and Immunity 80: 1333-42.

[103] Shearer, J. K., Harris, B. Jnr. (2003): Mastitis in Dairy Goat. - UF/ IFAS Extension, University of Florida.

[104] Sima, H., Ebrahim, R., Hasan, M. (2009): A 3-year study of Escherichia coli O157:H7 in cattle, camel, sheep, goat, chicken and beef minced meat. - International Conference on Food Engineering and Biotechnology 9: 162-166.

[105] Soderlund, R., Hedenstrom, I., Nilsson, A., Eriksson, E., Aspán, A (2012): Genetically similar strains of Escherichia coli O157:H7 isolated from sheep, cattle and human patients. - BMC Veterinary Research 8: 200.

[106] Songer, J. G., Post, K. W. (2005): The Genus Clostridium. - In: Songer, J. G., Post, K. W. (eds.) Veterinary Microbiology, Bacterial and Fungal Agents of Animal Disease. Saunders, Philadelphia, USA, pp. 261-282.

[107] Spiehs, M., Goyal, S. (2007): Best Management Practices for Pathogen Control in Manure Management Systems. - University of Minnesota Extension, St. Paul, MN, USA.

[108] Stecher, B., Hardt, W. D. (2008): The role of microbiota in infectious disease. - Trends Microbiology 16: 107.

[109] Stoddard, C. S., Coyne, M. S., Grove. J. H. (1998): Fecal bacteria survival and infiltration through a shallow agricultural soil: timing and tillage effects. - Journal of Environmental Quality 27: 1516-1523.

[110] Swift, J. M., Foster, D. M., Rogers, A. T. (2017): Efficacy of an Escherichia coli O157:H7 SRP vaccine in orally challenged goats and strain persistence over time. Foodborne Pathological Diseases 14: 160-6.

[111] Tahamtan, Y. E., Pourbakhsh, S. A., Shekarforoush, S. S. (2006): PCR detection of Escherchia Coli O157:H7 directed from slaughtered cattle in Shiraz, Iran. - Archives Razi Institute 61: 1-6.

[112] Tewari, A and Abdullah, S. (2015): Bacillus cereus food poisoning: international and Indian perspective. - Journal of Food Science Technology 52(5): 2500-2511.

[113] Titilawo, Y., Larry Obi, L., Okoh, A. (2015): Occurrence of virulence gene signatures associated with diarrhoeagenic and non-diarrhoeagenic pathovars of Escherichia coli isolates from some selected rivers in South-Western Nigeria. - BMC Microbiology 15: 204.

[114] Tomita, G. M., Hart, S. P. (2001): The Mastitis Problem. - 16th Annual Goat Field Day, Langston University, Langston, OK. 
[115] Topp, E., Welsh, M., Tien, Y., Dang, A., Lazarovits, G., Conn, K., Zhu, H. (2003): Strain dependent variability in growth and survival of Escherichia coli in agricultural soil. FEMS Microbiology Ecology 44: 303-308.

[116] Trawińska, B., Polonis, A., Tymczyna, L., Popiołek-Pyrz, M., Bombik, T., Saba, L. (2006): Bacteriological and parasitological pollution of the environment and birth health state around the reproductive layer farm. - Annales Universitatis Mariae CurieSkłodowska Sectio EE Zootechnica 24: 371-376.

[117] Van Kessel, J. S., Pachepsky, Y. A., Shelton, D. R., Karns, J. S. (2007): Survival of Escherichia coli in cowpats in pasture and in laboratory conditions. - Journal of Applied Microbiology 125.

[118] Wang, L., Mankin, K. R., Marchin, G. L. (2004): Survival of faecal bacteria in dairy cow manure. - Transactions of the ASAE. American Society of Agricultural Engineers 47: 1239-1246.

[119] Whitman, W. B., Coleman, D. C., Wiebe, W. J. (1998): Prokaryotes: The unseen majority. - Proceedings of the National Academy of Sciences of the United States of America 85: 6578-6583.

[120] Wieser, A., Schneider, L., Jung, J., Schubert, S. (2012): MALDI-TOF MS MS in microbiological diagnostics - identification of microorganisms and beyond (mini review). - Applied Microbiology and Biotechnology 93: 965-974.

[121] Ziemer, C. J., Bonner, J. M., Cole, D., Vinjé, J., Constantini, V., Goyal, S., Gramer, M., Mackie, R., Meng, X. J., Myers, G., Saif, L. J. (2010): Fate and transport of zoonotic, bacterial, viral, and parasitic pathogens during swine manure treatment, storage, and land application. - Journal of Animal Sciences 88: 84-94. 